IMMIGRANT WOMEN WORKERS IN THE SETTLEMENT SECTOR: NICHE EMPLOYMENT OR OCCUPATIONAL SEGMENTATION? A COMPARATIVE STUDY OF GERMANY AND CANADA

$$
\text { by }
$$

Sita Jayaraman, MA, Jawaharlal Nehru University, New Delhi, 1991

\author{
A Major Research Paper \\ presented to Ryerson University \\ in partial fulfillment of the requirements for the degree of \\ Master of Arts \\ in the Program of \\ Immigration and Settlement Studies
}

Toronto, Ontario, Canada, 2014

(C) Sita Jayaraman 2014 


\section{AUTHOR'S DECLARATION FOR ELECTRONIC SUBMISSION OF A MAJOR RESEARCH PAPER (MRP)}

I hereby declare that I am the sole author of this Major Research Paper. This is a true copy of the MRP, including any required final revisions.

I authorize Ryerson University to lend this MRP to other institutions or individuals for the purpose of scholarly research.

I further authorize Ryerson University to reproduce this MRP by photocopying or by other means, in total or in part, at the request of other institutions or individuals for the purpose of scholarly research.

I understand that my MRP may be made electronically available to the public.

Sita Jayaraman 


\title{
Immigrant Women Workers in the Settlement Sector: Niche Employment or Occupational Segmentation? A Comparative Study of Germany and Canada
}

\author{
(C) Sita Jayaraman 2014 \\ Master of Arts \\ Immigration and Settlement Studies \\ Ryerson University
}

\begin{abstract}
Much of the research on the settlement sector in Germany and Canada focuses on the range and impact of settlement programs as well as funding to the sector. The settlement sector as a field of employment for immigrant women is an emerging area of research. The purpose of the paper is to analyze and compare the experiences of immigrant women working in the settlement sector in Germany and Canada. The central thesis of the research is that immigrant women working in this sector experience occupational segregation based on their gender, race and immigrant status. The research findings support this thesis, as the settlement sector reveals itself as a deeply segmented labour market, where language and cultural competencies may have facilitated racialized, immigrant women's employment, yet the roles they occupy are characterized by precarious working conditions with limited opportunities for professional growth.
\end{abstract}

Keywords: immigrant women, labour market experiences, settlement services, occupational segmentation 


\section{ACKNOWLEDGEMENTS}

Thank you to Harald Bauder, whose guidance, wisdom and encouragement enabled me to go beyond my comfort zone to explore new and old territories, while staying focused on my research objectives. Thank you also to Vappu Tyyskä for the thought provokingcomments and contributions as my second reader.

Thank you to all the participants who candidly shared their knowledge and experiences with me. 


\section{DEDICATION}

I dedicate this paper to my husband and my daughters, who believed in me and insisted that I board the train to go to my first class - my first step in the journey. Without you, I would not have stayed the course. 


\section{TABLE OF CONTENTS}

$\begin{array}{lr}\text { INTRODUCTION } & 1\end{array}$

THEORETICAL FRAMEWORK 2

Labour Market Segmentation Theory 2

Theory of Social Closure $\quad 3$

MODELS OF SETTLEMENT SERVICE DELIVERY 4

Historical Context of Immigration $\quad 6$

Government Investment in Promoting Integration/Settlement $\quad 7$

Service Delivery through Non-Governmental Settlement Agencies 11

Comparing Settlement Services in Germany and Canada 16

LABOUR MARKET EXPERIENCES OF IMMIGRANT WOMEN 17

$\begin{array}{lr}\text { Germany } & 18\end{array}$

Canada 22

Comparing Labour Market Outcomes in Germany and Canada 28

$\begin{array}{lr}\text { METHODOLOGY } & 29\end{array}$

Research Design $\quad 29$

Participant Demographics and Recruitment 30

Ethical Considerations

FINDINGS

Who is Working in the Settlement Sector? 31

What are the Working Conditions in the Settlement Sector? 38

What kinds of Roles are Immigrant Women performing? 44

Comparing Immigrant Women Workers in Germany and Canada 48

$\begin{array}{ll}\text { RECOMMENDATIONS } & 49\end{array}$

$\begin{array}{ll}\text { CONCLUSION } & 50\end{array}$

APPENDIX A - Recruitment Script $\quad 54$

APPENDIX B - Interview Guide $\quad 55$

$\begin{array}{ll}\text { REFERENCES } & 57\end{array}$ 


\section{Introduction}

The purpose of the study is to analyze and compare the experiences of immigrant women working in the settlement sector in Germany and Canada. German and Canadian labour markets are inherently segmented, with women being overrepresented in jobs with lower incomes, minimal job security and little opportunity for growth and promotion. As immigrant women enter the segmented job market, their position is further exacerbated by their immigrant status and race, placing them in the bottom half of the secondary job market. The experiences of immigrant women as providers of settlement services are an understudied phenomenon. Most employment in this sector is short term, based on annual funding agreements, underpaid, part time and with limited opportunities for growth. While immigrant women are disproportionately represented in frontline work, senior management positions are held by nonracialized, non-immigrant men and women. The study will include an analysis of models of settlement services in Germany and Canada, a review of immigrant women's experiences in the labour market and key informant interviews with individuals working in the sector. The central thesis is that working in this sector creates segregation within the labour market and limits opportunities for growth for immigrant women. The research will seek to explore three main questions: a) Who is working in the sector?; b) What are the working conditions in this sector?; and c) What kinds of roles are immigrant women performing? Roles in the context of this research are defined as the kinds of tasks performed by immigrant women workers. Frontline workers are the first point of contact with clients and provide a range of services including information and referral. Management 
positions include supervisory and decision-making tasks with regards to agency policies and procedures. The paper will identify gaps in research and conclude with recommendations for policy development. The research will contribute to the emerging literature in the field of immigrant women's experiences and labour market outcomes, as providers of services in the settlement sector.

\section{Theoretical Framework}

The prevalence of immigrant women workers in the settlement sector will be examined in the context of two theories - labour market segmentation and social closure to understand the consequences of gender, immigrant status and race on labour market outcomes for immigrant women.

\section{Labour Market Segmentation}

Fundamental divisions among workers based on race, gender and educational credentials form the basis of Reich, Gordon and Edward's (1973) analysis of labour market segmentation. The authors propose that outcomes in the labour market are the result of four segmentation processes including segmentation by primary and secondary markets, segmentation within the primary sector, segmentation by race and lastly, by gender (Reich, Gordon \& Edward, 1973). The settlement sector as a labour market can be analyzed in the context of a secondary job market characterized by low wages, high turnover, minimal opportunities for growth and primarily filled by minority groups and women. Segmentation by race and gender is particularly evident in the settlement sector, where frontline jobs are occupied primarily by racialized women in roles that require caregiving or serving. Bauder (2003) lends an additional dimension to the literature on labour market segmentation by exploring segmentation of immigrant and ethnic labour based on employer perceptions of immigrant labour market motivations, 
which could explain the ability of immigrant women to find employment in the settlement sector. In the same context, the notion of embodied cultural capital as outlined by Bauder (2006) served to understand how certain behaviours, gestures and mannerisms become signifiers of competence, making these a desirable asset in the labour market in certain occupational segments such as for waiters and staff at ethnic restaurants. This approach can be useful in examining how racialized workers are more likely to find jobs in the immigrant serving sector while interacting with other racialized immigrants and how these very same behaviours, mannerisms and gestures can lead to exclusion in the labour market outside the settlement sector. Bauder (2006) refers to this practise as "cultural segmentation of labour" (p. 45).

The understanding that the human service sector is segmented by gender and race is substantiated by the fact that $82 \%$ of the workers in the sector are women, of whom $11.3 \%$ are racialized women working in the health care and social assistance fields (Block and Galabuzi, 2011). Boyd's (1984) research on occupational attainment among foreign born women reinforces the notion of gender being a key factor in determining women's participation in the labour market. She makes the point that the Canadian labour market is inherently segmented, with women being overrepresented in jobs with lower incomes, minimal job security and little opportunity for growth and promotion. She reports that as immigrant women enter the segmented job market, their position is further exacerbated by their immigrant status and race, placing them in the bottom half of the secondary job market.

\section{Theory of Social Closure}

The origins of the theory of social closure can be traced back to Weber (1958), wherein with respect to specialized education from colleges and universities, he states 
that this is not a sudden "thirst for education, but the desire for restricting the supply for these positions and their monopolization by the owners of educational certificates" ( $p$. 241). Weber's theory can be understood in the context of dominant groups monopolizing access to resources and opportunities to protect their own interests, while simultaneously excluding others from access to the very same opportunities and resources based on factors such as gender and race (Murphy, 1985). Murphy (1985) refers to credentialism as a form of closure that creates an artificial scarcity of services resulting in spiking prices for these services and granting "the chosen a legal, stateenforced basis for profiting from and appropriating the labour and skills of other workers” (p. 236). Witz (1990) further sharpens the understanding of social closure from a gender lens, asserting that within a patriarchal society, women have unequal access to resources and are unable to mobilize power to safeguard their interests. Citing the field of medicine as an example, Witz (1990) eloquently outlines the strategies of male doctors and counter strategies of female midwives to promote exclusion within their ranks. The phenomenon of immigrant women in the settlement sector can be understood in the context of exclusion from professions in the labour market as well as a counter strategy by immigrant women to create a specific employment niche.

In summary, labour market segmentation processes and social closure provide a framework for analyzing the reasons for employment and labour market outcomes of immigrant women in the settlement sector based on gender, race and immigrant status.

\section{Models of Settlement Service Delivery}

It is important to understand the contexts of settlement service delivery in Germany and Canada to analyze the labour market outcomes of immigrant women in both countries. The following sections examine the role of the federal, provincial and 
municipal governments in the delivery and funding of settlement services in Germany and Canada, assess the structure and role of local non-governmental, integration/settlement agencies in delivering services, including sources of funding and working conditions within the sector; and lastly, compare immigrant settlement service delivery in Germany and Canada. The term integration is used to describe services for newcomers in Germany, while settlement is the commonly used term for newcomer programs in Canada.

Germany and Canada, despite being continents apart, share a long history of immigrant arrivals that have shaped the economic and social landscape of their respective countries. As per the UNDP Human Development Report (2009), Canada is home to about 6.3 million immigrants, representing $19.5 \%$ of the population and Germany has about 10.5 million immigrants representing $12.9 \%$ of the population. However, Germany and Canada have experienced very diverse trajectories towards settlement service provision based on official public policy towards immigration

The formal recognition of Germany as a country of immigrants took place as late as in 2005 with the establishment of the Residence Act (Zuwanderungsgesetz), wherein the responsibility for integration programs was vested in all three levels of government along with local civil society organizations (Siemiatycki and Triadafilopoulos, 2010). The objectives of the integrations courses for recent and long term immigrants are to impart language training and information about Germany's culture, legal system and history.

The growth of the settlement sector in Canada can be traced back to the 1970 s and the range of services include information and referral, counselling, housing, employment services, language instruction, interpretation and health services (Amin, 
1987). Most settlement services are provided by community based or non-profit agencies and funded by the three levels of government, foundations and private funders (Richmond \& Shields, 2005).

\section{Historical Context of Immigration}

Understanding the history of immigration to Germany and Canada is critical for an analysis of the evolution of the settlement service sector in each of the countries. The 1960s and 70s witnessed a large influx of guest workers to Germany from Italy, Spain, Greece and Turkey as part of the recruitment scheme for manual labour (Kogan, 2011). The guest workers were not perceived as permanent immigrants and were expected to return to their country of origin after a few years in Germany. However, many of the guest workers did not return and their children and spouses came to Germany in the mid-70s and mid-80s. In the following decades, Germany witnessed a surge in asylum seekers, opening its borders to returning co-ethnic Germans in the 1990s. Since the turn of the century immigrants from Africa, Eastern Europe and the Middle East have accounted for a large share of immigrant arrivals (Kogan, 2011).

Canada has a history of immigration going back 500 years to the first European contact in 1497 (Kelley and Trebilcock, 2010). Kelley and Trebilcock trace the demand for labour as a critical factor in shaping immigration patterns from the time of the industrial revolution in the late 1800 s and Canada's evolution from a stated goal of fostering a white nation in the early 1900 s to one that welcomes racial diversity by the 1960s (2010). Immigrants to Canada in the past 30 years have come from nearly every corner of the world, representing over 200 countries primarily under three main immigration categories - Economic, Family and Refugee (Mills, 2006). In 2012, Canada admitted 257,515 newcomers under the above-mentioned immigration categories (CIC, 
2013). The demographic profile of immigrants has changed considerably since the 1990s, with a record number of 1.8 million immigrants arriving in one decade, the majority of who were visible minorities from Asia (Lim, Lo, Siemiatycki, \& Doucet, 2005).

\section{Government Investment in Promoting Integration/Settlement}

Germany. The Residence Act of 2005 in Germany laid the foundation for a national strategy to foster integration of foreign residents living legally in Germany (Siemiatycki \& Triadafilopoulos, 2010). The federal government committed 750 million Euros for direct integration programming, with additional funds being allocated for programs to target families and strengthen educational and labour market outcomes for people with migration backgrounds (Die Bundesregierung, 2007). The 2007 National Integration Plan outlines strategic initiatives by the Federal Government for strengthening language development for children, providing integration courses which focus on standardized language training and orientation courses for adults. Integration courses include 900 hours of language training and 45 hours of training on German history, culture and legal system (Siemiatycki \& Triadafilopoulos, 2010). For immigrants from outside the EU states known as Third Country Nationals, the integrations courses are mandatory if they are drawing unemployment benefits or if they are deemed to be requiring special need for integration. (Siemiatycki \& Triadafilopoulos, 2010). In addition to funding programs for integration, the Federal government has committed to increasing the number of people with immigration background in the government and promoting diversity in the private sector through campaigns and contests (Die Bundesregierung, 2007). 
The Länder (states/provinces) play a coordinated role alongside the Federal Government in immigrant integration. The recognition that barriers to integration are posed by lack of language skills, spatial isolation and ethno-specific silos has led to the development of a number of state level programs in pre-school and elementary schools. The programs are aimed at promoting multi language ability, training existing teachers in intercultural competence and hiring teachers and social workers who have migration background. Additional programs address recognition of foreign credentials, improving access to healthcare for seniors, promoting civic engagement and collaborating with diverse religious institution, particularly Islamic faith groups (Die Bundesregierung, 2007).

Within the framework of the larger national strategy outlined in the Residence Act, each state is able to set its own particular focus, based on local needs. For example, The State of North Rhine-Westphalia makes quarterly transfer payments of 1,050 Euros per person to the municipalities to provide integration services related to counseling, housing and information provision (Ministerium für Arbeit, Integration und Soziales des Landes Nordrhein-Westfalen, 2012).

The National Integration Plan envisages the role of the municipalities as liaising between the people, state and federal government to elevate issues concerning people with immigrant backgrounds. The municipalities are charged with documenting best practices, coordinating local efforts between stakeholders engaged in integration initiatives, maintaining intercultural competence as a focus of customer service, increasing the number of employees with immigration background, involving immigrants in decision making processes, promoting local ethnic economies and addressing xenophobia and promoting tolerance (Die Bundesregierung, 2007). More 
recently, discussions at the municipal level are increasingly focusing on empowering immigrant self-help organizations. A new directive within the Berlin Senate Administration for Labour, Integration and Women is to support immigrant organizations to become self-sufficient and build organizational capacity (Berlin.de, 2013).

Given Germany's long history of immigration from different parts of the world at different times, the discourse in Germany revolves around the notion of people with immigration background, whereby length of residence in Germany is not the central qualifier for services. The integration courses are designed for long term and recent newcomers who experience xenophobia and barriers to access education and employment.

Canada. The Federal Ministry Citizenship and Immigration Canada (CIC) is the central body in Canada that sets the framework for integration and settlement programs for immigrants to Canada. In 1974, the Immigrant Settlement and Adaptation Program (ISAP) was introduced to support the "adaptation, settlement and integration of newcomers to Canada" (CIC, 2011, p.1). CIC funded programs for newcomers under the ISAP, LINC (Language Instruction for Newcomers) and HOST program to help immigrants gain access to information about Canada, build language skills and connect with the mainstream community. The Modernized Settlement Program replaced ISAP, LINC and HOST in 2008 in order to offer greater flexibility for agencies to meet clients' needs, focus on outcomes and enhance accountability (CIC, 2013). Services provided under the six streams of the Modernized Settlement Program include Needs Assessment and Referral, Information and Awareness Services, Language Learning and Skills Development, Employment-Related Services, Community Connections and Support 
Services. In 2007/2008 with a total budget of 170.3 million, 188 service providers were funded, 92,235 clients served and 572,471 services offered (CIC, 2011). Clients eligible for service included permanent residents, live-in caregivers, persons who have applied for permanent residency as well as protected persons under the Immigration and Refugee Protection Act.

While different provinces have developed immigration and settlement policies, based on local needs and demographics, for the purposes of the major research paper, I will focus on Ontario and the Greater Toronto Area, in particular. Ironically, despite being the province of choice for half of all newcomers to Canada, Ontario has released its first ever official strategy for immigration as late as in November 2012 (MCI, 2012). The principle tenets of the new immigration strategy are to attract a skilled workforce for a stronger economy, support newcomers and their families to succeed and to foster a globally connected community. Services supported by the Ontario Ministry of Citizenship and Immigration (MCI) include Newcomer Settlement Programs (NSP), language training and Bridge Training Programs to help newcomers in licensed trades and professions get recognition for their foreign credentials and gain employment (MCI, 2013). Last year, the NSP program provided $\$ 7.5$ million in funding to 98 community based agencies, which collectively served an estimated 80,000 newcomers (MCI, 2013).

The role of municipalities in newcomer settlement is critical in view of the large number of newcomers coming to Canada. In 2010, over half a million -558,000 permanent residents and temporary residents flocked to Canadian cities and communities (Cappe, 2011). While Cappe states that municipal governments are neither mandated nor funded to provide immigrant settlement services, municipalities have incorporated settlement services as part of their operational plans and budgets (2011). 
Housing and public transportation have been identified as some of the key areas requiring urgent attention for successful immigrant integration. The absence of a formal constitutional role in developing policies for immigration and settlement notwithstanding, cities such as Edmonton have adopted policies specifically focusing on fostering economic integration, promoting public awareness and enabling equitable access to services for immigrants (Tossutti, 2009). Cities such as Toronto and Edmonton have collaborated with local immigrant employment councils comprising of diverse stakeholders from employers to educational institutions and representatives of the three levels of government to address economic integration of newcomers (Tossutti, 2009).

\section{Service Delivery through Non-Governmental Settlement Agencies}

Germany. A review of the literature on settlement service delivery through nongovernmental organizations reveals that there are two distinct and differently funded models in operation - services offered by large mainstream, well-funded welfare associations and programs offered by a number of small to medium immigrant self-help organizations. An online handbook for newcomers to Düsseldorf lists a wide range of organizations that offer integration services for newcomers and it becomes evident that the bulk of the integration courses are delivered by traditional, well-funded, large welfare associations with full time staff and volunteers such as the German Red Cross (Deutsches Rotes Kreuz - DRK), Caritas, which is closely affiliated to the Catholic church in Germany, Diakonie (aligned with the Protestant church) and Arbeiterwohlfart (AWO), the Workers Association, closely linked to the Social Democratic Party in Germany (Landeshauptstadt Düsseldorf, 2013). Integration services offered by these organizations include needs assessment, information and 
counseling and initiatives to promote volunteerism for immigrants and combat discrimination. The near monopoly of the 3-4 larger organizations in getting government funding for services has been documented by Zimmer in an extensive analysis of the third sector in Germany (2000). Zimmer (2000) refers to the principle of subsidiarity, where the government acknowledges the role of non-government agencies in delivering public welfare and social services and subsequently funds the bulk of the operating costs. Zimmer estimates that the government provides over $60 \%$ of nonprofit revenue income, $32 \%$ is derived by agencies from user fees and charges and 3,4\% from philanthropic contributions (2000). She further states while stable funding from the government minimizes the impact of market fluctuations, the organizations are vulnerable to government policy changes, making them quasi government organizations. North Rhine-Westphalia for instance provides up to $90 \%$ subsidy for employment in settlement agencies (Ministerium für Arbeit, Integration und Soziales des Landes Nordrhein-Westfalen, 2012). The agencies are mandated to hire employees with a post-secondary education in social work, education or psychology. Funding for integration courses is available from diverse sources such as the Ministry for Migrants and Refugees (BAMF), EU -Social Funds Stream, the Ministry for Education and Research, Ministry for Families, Seniors, Women and Youth and Ministry of Labour, responsible departments within the state governments and at the municipal level, from foundations, unions, corporations and associations, making immigrant integration a cross-sectoral priority (BAMF, 2013).

The role of immigrant self-help organizations (SHOs) or Migrant Organizations (MOs) in promoting integration was a polarizing debate in the 70s and 80s in Germany, divided between those who favored MOs as providers of information on day to day 
practices, and advocates for immigrants and those who opposed MOs, as they were perceived to create silos within society based on the ideology that institutional completeness leads to more segregation (Hunger, 2008). There has been a change in perception in the last decade and increased acknowledgement about the role of immigrant organizations as partners in providing integration services. There are an estimated 6,00o registered immigrant MOs in Germany formed on shared ethnospecific or national identities and political ideology as well as professional associations of teachers, lawyers or social workers with migration background, whose mandate is to provide language training, education to children and professional training for adults (ZSD, 2011). Some of the bigger MOs such as the Turkish Community Association have up to 50 employees, while others are smaller with up to 20 employees (ZSD, 2011). A recent evaluation of government supported MOs estimates that over $30 \%$ of all projects supported by the Ministry for Migration and Refugees are carried out by established organizations such as Caritas or Diakonie in partnership with immigrant organizations such as Africa Positive, Association of Islamic cultural organizations and multicultural family associations (Beer \& Ernst, 2012). The growing government support to MOs notwithstanding, Beer and Ernst (2012) make reference to the lack of financial stability within MOs to employ full time staff and the predominance of volunteer work in the sector. Bartels notes that integration programs are primarily run by volunteers in MOs, who have very limited knowledge of available networks and funding opportunities (2009). While a number of studies and conferences have focused on the constraints faced by MOs, very little has been published about the workers or volunteers in the sector, pay scales or job stability. There are gaps in research on the profile of workers in German MOs. 
Canada. Canada has a robust settlement sector, characterized by numerous large, multi-service organizations and smaller ethno-specific organizations which provide information and referral, counselling, housing, employment services, language instruction, interpretation and health services for newcomers. Examples of large multiservice organizations in the Greater Toronto Area include agencies such as Centre for Education and Training, Halton Multicultural Council, Dixie-Bloor Neighbourhood Services and COSTI and smaller agencies include the Punjabi Community Health Services, the Menonite New Life Centre and African Community Services of Peel. The majority of the funding is provided by the three levels of government, foundations and private funders (Richmond \& Shields, 2005). Sadiq and Doucet refer to the phenomena of a two-tier settlement system, whereby the larger, multi service agencies, which have the skills to apply for government funding, sub contract to smaller ethno-specific agencies to fill gaps in terms of language or cultural competence, which leads to inherent power imbalance and threatens the very survival of smaller agencies, while exposing the workers to the risks of precarious employments (2004). Richmond and Shields (2005) report that inadequate funding for community service agencies providing settlement services has led to gaps in services, instability and worsening conditions for staff working in the sector. The Alberta Network of Immigrant Women (ANIW) documented in 2006 that reduced funding had led to an increase in part-time, contract positions and increased workload meant that performance reviews had not been conducted, workers had not been supported and there was minimal on the job training or orientation.

Lee (1999) argues that the settlement sector in Canada was created as a parallel to the social service sector, as immigrants did not fit the traditionally held 
understanding of a client. Her research revealed that $80 \%$ of workers in the settlement sector are women and over $70 \%$ are first generation, racialized immigrants working in frontline and counseling jobs, leading her to conclude that the sector has led to occupational segregation that promotes the employment of racialized women in the settlement sector. In a more recent study on immigrant workers in the settlement sector Türegün (2011) asserts that immigrants entering the labour market have three choices "exit, deprofessionalization, or professional rebuilding" (p. 6). He concludes that working in the settlement sector is an active choice for professional rebuilding aided by the lack of rigid professional standards in this sector and immigrants' desire to give back to the community. This line of argument is questionable as increasing numbers of job postings in the sector on websites such as www.settlement.org require certification or post-secondary education in social work or immigration and settlement.

The required skills for workers in the sector range from understanding cultural norms and values of immigrant populations, multi-lingual abilities and ability to counsel to a thorough knowledge of government resources available for immigrants (Amin, 1987). While the range of skills required is vast, the pay scales are not competitive when compared to the corporate sector. Nearly two-thirds of workers reported average income of $\$ 30,000-\$ 40,000$ per annum compared to average wages of $\$ 49,540$ in other sectors (Wilson, 2006). Lee (1999) makes an astute observation on institutionalized volunteerism within the sector, where volunteerism takes the place of paid employment. Under the guise of acquiring Canadian work experience, she reports that immigrant women are exploited and often end up providing unpaid clerical support. 


\section{Comparing Settlement Services in Germany and Canada}

Based on the review of literature on non-governmental agencies providing settlement and integration services in Germany and Canada, there are a number of key similarities as well as some differences. The following is a summary of the salient commonalities and differences in both countries:

$>$ Germany has developed a national plan to foster integration of immigrants in 2005, mandating and resourcing all three levels of government. Canada is yet to develop a national plan and in fact, municipalities have no constitutional role in immigrant settlement.

$>$ In Germany, funding for integration courses is available from diverse sources such as the Ministry for Migrants and Refugees (BAMF), EU -Social Funds Stream, the Ministry for Education and Research, Ministry for Families, Seniors, Women and Youth and Ministry of Labour, responsible departments within the state and municipal governments making immigrant integration a cross-sectoral priority. In comparison, in Canada, the Federal and Provincial Ministries of Citizenship and Immigration are the primary funders of settlement services, without comprehensive cross-sectoral support from a variety of other government departments.

$>$ Settlement services are provided by a range of large, well established organizations such as Caritas, Diakonie and Red Cross, which also provide a number of non-immigrant related services to the wider community in Germany. The ability to provide settlement and mainstream services has had a financially stabilizing impact on agencies. There appears to a much more rigid divide in Canada, with agencies being either dedicated to settlement 
work or mainstream social services, creating silos and a patchy network of services for newcomers and increased financial instability within organizations.

$>$ The phenomenon of smaller, resource strapped immigrant self-help organizations and MOs appears to be common in both countries. Gaps in basic infrastructure, stable funding and capacity building within the sector has impacted the ability to deliver programs and attract and retain well qualified staff. Lack of full time jobs and the over utilization of volunteers within MOs in Germany and smaller ethno-specific agencies in Canada impacts the quality of services offered. The lack of published research on wages and compensation for workers in German MOs makes it challenging to compare working conditions in Germany and Canada.

In summary, public policy and government funding have set the framework for immigrant settlement and integration. Germany's national strategy including all levels of government and cross-sectoral involvement for immigrant integration holds promise, but it is too early to judge the impact of the programs. Canada lacks a comprehensive national strategy involving all three levels of government, which has had a debilitating impact on settlement agencies that are left coping with volatile funding and uncertain working conditions. In order to build a strong and vibrant settlement sector, Germany and Canada need to continue to involve all stakeholders including big and small agencies and strengthen their commitment to immigrant integration.

\section{Labour Market Experiences of Immigrant Women}

Given the paucity of research on labour market outcomes for immigrant women specific to the settlement sector, it is vital to understand the broader context of 
immigrant women's labour market experiences and relate these to their outcomes within the settlement sector. A comparative analysis of existing research in Germany and Canada on immigrant women's labour market experiences and outcomes points to fundamental differences in researchers' frameworks for understanding labour market outcomes. Research in both countries points to the fact that immigrant women experience lower levels of success and encounter barriers to labour market participation. However, in Germany, these differences are attributed to the legal status of immigrant women and the human capital theory. Acknowledgements of systemic barriers in the form of xenophobia and discrimination are just beginning to emerge within the German context. In contrast, given the legal framework in Canada and the long term acknowledgement of Canada as a country of immigrants, Canadian research on immigrant women focuses on gender, immigrant status, credentialism and systemic barriers such as racism to understand differences in labour market outcomes between immigrant women and native born Canadian women. The following sections review the literature in each country to uncover the labour market outcomes and reasons for differences in outcomes.

\section{Germany}

The literature on immigrant women's experiences in the German labour market has largely focused on 1) the legal framework impacting immigrant women's access and outcomes in the labour market, 2) the human capital theory to explain differences in labour market outcomes among different categories of immigrant women and the native born, 3) labour market segmentation and 4) discrimination/xenophobia leading to differential outcomes for immigrant women. While a majority of the literature 
acknowledges that immigrant women experience lower outcomes, there is no unanimous agreement on the root causes.

Immigrant women's legal status has been identified as one of the key factors impacting labour market access. EU Citizenship in Germany is required to access public sector jobs and teaching positions in schools, which adversely impacts immigrant men and women (Kesler, 2006; Mushaben, 2009). Mushaben (2009) further clarifies that immigrant women are constrained by the German policy of issuing temporary visas granting contractually limiting work permits. Steinhardt (2012) reports that while naturalized women earn more than their non-naturalized counterparts, it is not significant, because even naturalized women are employed in high numbers in cleaning, healthcare and household, where German citizenship does not provide any additional leverage (p. 819). Rubin et al. point out that women in recent years have been arriving as spouses in the context of family reunification or as refugees and asylum seekers, which does not entitle them to work, which immediately places them at a disadvantage vis à vis their male counterparts (2008). Women coming to Germany under the reunification category have restricted access to paid labour opportunities for the first two years, which severely limits their ability to gain permanent residence status, as workers have to contribute to the social insurance system to gain permanent residence status (Rubin et al., 2008). The authors highlight the double whammy for women, as women are often the ones taking up child care duties while their spouses take on paid employment. While time spent on child care counts towards workers' contribution records, it is not enough to gain unrestricted residence permit (Rubin et al., 2008). Germany's restrictive policies towards non-citizens have limited immigrant and refugee women's access to well-paid and stable jobs in the labour market. 
The vast amount of literature on immigrant women's labour market outcomes revolves around the human capital theory - linking educational attainment to income, occupational status and employment rates. There appears to be consensus among a number of researchers that immigrants have higher unemployment rates and lower incomes due to lower educational attainment, lack of job market specific knowledge, language skills and work place culture (Kalter \& Granato, 2002; Gundel \& Peters, 2008; Stichs, 2008; Dustmann \& Schmidt, 2001; Neidhart, 2001; Constant \& Massey, 2005).

Stichs in her extensive comparative research on labour market integration outcomes among different ethnic groups of immigrant women in Germany states that the probability of being employed has less to do with source country of immigration and more to do with qualifications, age, length of residence, number of children, knowledge of German, marital status, level of education, first or second generation status (2008). Stichs (2008) reports that second generation women experience better outcomes because of better language skills and educational qualifications. It is to be noted that Stich's study was commissioned by the German Ministry of Migration and Refugees, which may have impacted the outcome of the study. Stich also acknowledges that first generation women whose educational credentials are recognized in Germany fare better, but are still unable to leverage it for career advancement to the same extent as the second generation women (2008). An explanation of the causes or systemic barriers for this phenomenon is not offered by the author.

A distinct, somewhat contradictory trend appears to be emerging in studies and the media since 2009, where in contrast to the human capital theory, there is an attempt to identify issues such as discrimination, devaluing of foreign credentials, occupational segmentation and sexism, as significant factors influencing immigrant women's 
experiences in the labour market. Several studies have reiterated that immigrant women are disproportionately occupied in the secondary job market, overwhelmingly employed within the three Cs - Cooking, Cleaning and Caring, experiencing lower pay, longer spells of unemployment and lower job mobility when analyzed in the context of the European Union as a whole, as well as specific to the German context (Dustman \& Schmidt, 2001; Kofman \& Raghuram, 2009; Kogan, 2011; Kral, Roosblad \& Wrench, 2009; Steinhardt, 2012; Mushaben, 2009; Lutz, 2008). Kral, Roosblad and Wrench (2009) state that in 2004, the hotel industry, a sector characterized by low skilled jobs, employed $11.5 \%$ of foreign women and $3.8 \%$ of native born women. Their findings revealed that the percentage of women overqualified for the jobs they were doing was $10 \%$ for native born women, $23.6 \%$ for foreign born and $32.3 \%$ for foreign born non OECD country women (2009). Lutz speaks to the growing phenomenon of immigrant women from East Europe, Africa, Asia and Latin America working as caregivers in German households illegally (2008). A pioneering 2010 study by Jungwirth is a systematic endeavour to disprove the myth that immigrant women experience lower outcomes due to lack of education (Deutsche Tuerkische Nachrichten, 2010). Jungwirth traces the employment paths of immigrant women with university education in the MINT (Mathematics, Information, Natural sciences and Technology) subjects and found that their qualifications were not recognized. She attributes this to the lack of recognition of foreign credentials, inadequate access to appropriate language training and inadequate support provided by employment agencies. According to Jungwirth, highly qualified immigrant women have the best chances of finding employment in retail, hospitality, office administration and financial service industry (2010). Kogan (2011) concludes that for immigrants coming to Germany in the 60s and 70s, lower 
educational levels explained the difference between outcomes for natives and immigrants, but for those arriving after the 1990s, who are highly qualified, their education "is practically useless for access to suitable occupations" (p. 113).

Xenophobia as a cause for discrimination in the labour market found mention in a number of studies, especially with reference to immigrants of Turkish origin. Mushaben states that xenophobia has led to Turkish women turning to self-employment - operating travel agencies, hair salons and offering services in the food industry, alterations and cleaning (2009). She notes that wearing of the head scarf has led to exclusion from the mainstream labour market (2009). Authors such as Kesler (2006) speak to "resistance to diversity" and "ethnically exclusionist" (p. 747) attitudes as barriers to labour market access for immigrants. Terms such as employer reservation are used by organizations working on issues of discrimination to explain the higher rates of unemployment among immigrant women (Antidiskriminierungsverband Schleswigholstein, 2013). Lending credibility to the theory of xenophobia, Kaas and Manger's field experiment revealed that applicants with Turkish sounding names got fewer call backs for an internship position when compared to applications with German sounding names (2012).

As evidenced by the literature examined, immigrant and refugee women in Germany, particularly from non EU countries encounter occupational segmentation, lack of recognition of foreign credentials, limited access to public sector jobs, underemployment, xenophobia and sexism within the labour market.

\section{Canada}

The literature on immigrant women's experiences in the Canadian context has focused on the impact of gender, visible minority status, race, immigrant status and 
length of stay (Lightman \& Gingrich, 2013; Boyd, 1984), non-recognition of foreign credentials, systemic racism and employer perceptions of Canadian work experience (Banerjee, 2009; Pendakur \& Pendakur, 1996; Li, 2001; Wang 2008; Man 2004) on immigrant women's participation and occupational attainment in the labour market. While there are differences in the analysis of why immigrant women are underperforming in the Canadian labour market, there is agreement that immigrant women are increasingly employed in precarious employment with low wages, temporary work and minimal benefits (Block \& Galabuzi, 2011; Li, 2001; Pendakur \& Pendakur, 1996). Lightman and Gingrich (2103) state that "those most likely to experience multiple pressures toward economic exclusion in Canada's labour market are young new immigrant and racialised women" ( $\mathrm{p} 138$ ). This section will examine the different causes that shape immigrant women's labour market outcomes.

Institutional barriers impact women's participation in the labour market even before the point of entry and persist post arrival in Canada. In 2009, 252,000 immigrants were admitted to Canada as permanent residents, of whom $52 \%$ were women (Chui, 2011). The majority of women immigrants came to Canada under the Family Class or as dependents in the Economic Class. A significantly lower percentage, under 20\% were admitted to Canada as Principal Applicants in the Economic Class (Chui, 2011). Analyzing Canadian immigration policies and their negative impact on women, Arat-Koc (1999) states that across the globe, women have less access to resources, education and employment and the selection criteria for immigration to Canada further marginalizes women, as it is intended to select only those who have considerable financial resources, high education from formalized institutions, speak at least one of the official languages and can demonstrate their potential in the Canadian 
labour market. With the recent reforms and changes in the immigration system, the Canadian government is rapidly moving to a system which awards preferential treatment to people with higher language skills and the ability to get their foreign credentials assessed in their home country before immigrating to Canada, which will filter out a larger number of women, given women's marginalized economic situation around the world (Al Masri, 2013).

Gender has been identified as a key factor in determining women's labour market outcomes. Boyd in her 1984 study on occupational attainment of foreign born women in Canada states that class, gender and country of birth are the major factor which negatively impact immigrant women, placing them in jobs in the secondary job market, which are characterized by precarious employment in low paying jobs with little opportunities for career advancement and growth. She refers to women's dual responsibility of caregiving within the household and financial need to work as the "double duty/double burden syndrome" (p.1092). She concludes that while immigrant women face challenges in the labour market, birth place has differential impact, with women born in the UK and USA experiencing fewer challenges with reference to discrimination by employers and hiring practices than women born elsewhere (Boyd, 1984, p.1114). Echoing Boyd's (1984) assertion of a double burden for women, Man (2004) states that the lack of a national child care strategy and absence of extended family for immigrant women have exacerbated their situation, further marginalizing their participation in the Canadian labour market, compelling women to take flexible and lower paying jobs to fulfill the dual responsibilities of paid and unpaid work.

There is a growing body of research that addresses the disconnect between high levels of education among recent immigrant women and highest levels of 
unemployment and lowest income levels among immigrant women who have arrived in Canada in the last two decades (Man, 2004; Mills, 2006). In this context, lack of recognition of foreign credentials has been identified repeatedly as a cause for lower outcomes for immigrant women (Pendakur \& Pendakur, 1996; Banerjee, 2009). Li (2001) asserts that educational qualifications acquired outside Canada are perceived as inferior to qualifications acquired in Canada resulting in immigrants making less money than native born Canadians, as their credentials are perceived as less marketworthy. He concludes that immigrants who have acquired their entire educational qualifications outside Canada have the lowest income. In his comparison of visible minority and white Canadian born women and men with university degrees, he found that white Canadian men were at the top of the income scale, followed by immigrant men from visible minority communities, while white Canadian born women ranked third and visible minority immigrant women last (Li, 2001).

Pendakur and Pendakur (1996) also addressed the issue of income gaps between Canadian born and immigrant workers and concluded that immigrant women who have an education from Asia or Africa earn 16\% less than those educated in Canada, confirming that place of schooling matters. Highlighting the impact of race on income in the Canadian labour market, Pendakur and Pendakur (1996) report that while immigrant status carriers "earnings penalties" (p. 24) for all immigrant women, immigrant women from visible minority communities face twice as high a penalty as white immigrant women. A decade after Pendakur and Pendakur's findings, Block's (2010) analysis of earnings of first generation immigrant women bears testimony to persistent earning gaps with first generation immigrant women with university education still trapped in the lowest income category. 
The notion of deskilling or devaluing of immigrant skills and work experience has been the subject of extensive research in the context of immigrant women's underperformance in the labour market. Man (2004) in her study of Chinese immigrant women speaks to the phenomenon of deskilling, whereby immigrant women are compelled to take up precarious employment due to a number of reasons ranging from race, gender, ethnicity and systemic barriers such as the need for Canadian work experience, lengthy and accreditation processes and lack of recognition of foreign credentials. Man (2004) cites the example of a number of trades and occupations that are licensed by professional associations, making it difficult for immigrants to enter these occupations without undergoing lengthy recertification processes. Wang (2008) differentiates between the real lack of skills or language and the perceived lack of skills by employers as the fundamental cause for discrimination and lower labour market outcomes. She states that while real gaps such as language fluency can be acquired through training or recertification and hard work by immigrants, the racist attitudes and perceived lack of skills and job related knowledge associated with lower language skills or accents, race and gender are structural barriers that are challenging to overcome and beyond the realm of control of immigrant women. Wang (2008) asserts that women's situation is further disadvantaged by the lack of social supports, additional responsibilities for care giving for extended family, primary share of household duties, child bearing, caregiving and expensive and elusive child care spots. Employer perception is well articulated in Oreopoulos's findings wherein his experiment demonstrated that resumes with Chinese, Indian or Pakistani names, education and experiences had a response rate for interviews of 5 percent, while resumes with English 
names and Canadian education and experience had a response rate of 16 per cent (Oreopoulos, 2009).

Lack of Canadian work experience has become a structural barrier for immigrant women's access to the labour market (Man, 2004, Boyd, 1984, Li 2001). Oreopoulos (2009) asserts that the interaction of ethnicity and Canadian work experience or lack thereof are key indicators of labour market outcomes. Oreopoulos (2009) reports that employers give weightage to Canadian work experience while screening resumes for employment and interviews. He suggests that there are a number of reasons for this preference, as employers may not be familiar with the work culture or nature of work of organizations in countries outside Canada. In his experiment with a sample of 6,000 resumes, those with ethnic sounding names, but entire education and work experience in Canada, had slightly lower call back rates than resumes with English names and Canadian experience and education. Subsequently, Oreopoulos (2009) concludes that the variable that is given the most significance is work experience. He reports that resumes with Canadian work experience, but foreign qualifications were treated more favourably than resumes with work experience outside Canada and education from Canada.

Race and systemic racism have emerged as a lens for analysis in studies relating to immigrant women's labour market outcomes. Galabuzi (2001) refers to a racially segmented labour market where racialized women immigrants in particular end up working in the bottom rung of jobs with low pay scales facing underemployment, unemployment, poverty, not represented in the better paid, management positions within stable, permanent jobs. He raises valid concerns that despite the Federal Employment Equity Act, a survey published in 2000 noted that at a time when 
racialized communities represented $11 \%$ of the population, they occupied less than $5 \%$ of federal jobs (Galabuzi, 2001). Block and Galabuzi's study on the growing racialization of poverty in Canada states that racialized immigrant women earn less than half (48.7 cents) for every dollar earned by a non-racialized immigrant man (2011).

\section{Comparing Labour Market Outcomes in Germany and Canada}

Based on the review of research in Germany and Canada, it becomes evident that a host of factors including the country's existing legal framework, immigration policies, employer perceptions and systemic barriers related to gender and race impact women's outcomes in the labour market. The following is a systematic comparison of the similarities and differences in immigrant women labour market outcomes in Canada and Germany:

$>$ Immigrant women in Germany and Canada face barriers based on legal framework with regards to citizenship in the German context and government policies regarding immigration selection in Canada. Canada's

legal framework and avowed multiculturalism grant immigrant women equal access to public and private sector jobs in principle, although they are overly represented in the secondary job market. Germany's legal restrictions and lack of legal status for immigrant women block their access to public sector jobs and restrict their access to private sector jobs, trapping them in secondary jobs.

$>$ Immigrant women in both contexts bear the consequences of patriarchy, which results in women being primarily responsible for caregiving. The primary responsibility of caregiving impacts women's ability to work full 
time, as they may be compelled to take flexible and lower paying jobs to fulfill the dual responsibilities of paid and unpaid work.

$>$ While the human capital theory is applied by many researchers to explain immigrant women's lack of success in the German context, immigrant women's barriers to labour market participation despite high levels of education in Canada is a well-documented fact. The recognition that women's education and skills are devalued in the German context as well is beginning to emerge.

$>$ Employer discrimination towards immigrant women based on gender, race, accent, knowledge and skills are common features inhibiting immigrant women's labour market outcomes in both contexts.

$>$ Labour market segmentation theories apply in both contexts as immigrant women continue to be trapped in precarious employment with low pay and minimal benefits.

\section{Methodology}

\section{Research Design}

The research objective is to explore three key areas a) Who is working in the sector?; b) What are the working conditions in this sector?; and c) What kinds of roles are immigrant women performing? A qualitative research method has been used to gather data through interviews with key informants working in the settlement sector. One to one, personal interviews lasting 40-50 minutes were conducted with seven key informants, four in Germany and three in Canada. Three of the interviews were conducted in the city of Düsseldorf and one in Duisburg in North Rhine-Westphalia, Germany, and two in Toronto and one in Peel Region in Ontario, Canada. North Rhine- 
Westphalia and Ontario are among the most diverse and populous states/provinces in each of the respective countries. All participants represented agencies in urban locations, which attract a large number of immigrants. Key informants were selected for the interviews, as they were able to provide a depth of knowledge of workers in the sector. The questions were open-ended and semi-structured to facilitate conversation about their observations on immigrant women as workers in the sector.

\section{Participant Demographics and Recruitment}

Participants were selected based on the information available on the internet about their agencies and their role within the agency. The key informants were individuals with 2-20 years of experience of working in the settlement sector. Of the seven key informants, there were two men and two women in Germany and two women and one man in Canada. In terms of functions and designations of the key informants, three were Executive Directors of their organization, one was the lead staff of a very small organization and two were Program Coordinators, performing frontline and some supervisory responsibilities. Four of the key informants were of immigrant background, two were native born and one did not disclose her background. They represent a broad range of organizations including two ethno-specific agencies, one religious community organization, one immigrant advocacy agency, one mainstream settlement agency and two national voluntary, welfare agencies. Six of the seven interviews were audio taped and transcribed verbatim. One of the key informants declined to be audio taped, hand written notes were taken during the interview. Four interviews were conducted in German and the quotes cited in the German context have been translated for the purpose of the Major Research Paper. Using a process of axial coding, themes and 
patterns in the interview responses were identified and summarized. All participants acted in a voluntary capacity.

Participants were contacted by email to ascertain their interest in participating in the study. Consent forms were emailed well ahead of the interview to give participants the opportunity to understand the scope of the study, assure them of the confidential nature of the interviews and ensure voluntary participation.

\section{Ethical Considerations}

A research ethics proposal was submitted prior to interviewing the key informants to consider potential risks to the interviewees and ensure confidentiality. The potential risks and discomforts involved in participation in the study were minimal. Risk was mitigated by maintaining confidentiality. Participants were made aware that they had the option of skipping a question or section. Informed consent was obtained prior to the start of the interview. The identity of the interviewee as well as the recorded data were kept confidential.

The following sections present the findings of the interviews conducted with the seven key informants categorized by country. The section also cites research findings, where available, that support the data gathered through the interviews.

\section{Findings}

\section{Who is Working in the Settlement Sector?}

Germany. The situation of workers in the German settlement sector has to be analyzed from two distinct perspectives given that a majority of the integration services are embedded within larger, well established welfare associations. The situation within these larger, well-funded agencies differ from the situation of smaller migrant self-help organizations (SHOs) described in the previous chapter. 
A study on work patterns in the non-profit sector in Germany states that "women represent $69 \%$ of the labour in the German non-profit sector, compared to $39 \%$ for the economy as a whole" (Anheier, Hollerweger, Badelt \& Kendall, 2013, p. 11). Confirming the above, Participant C stated "Generally, there are women in the social service sector, we know few men in the sector.... They are all female colleagues, we have 5 integration agencies, but only one male colleague." In an attempt to explain the large number of women in the field, Participant A stated:

In the social service department [of the agency], all staff are women, except for one man. There are more women than men. There is one man in the Kindergarten, no man wants to work [in the Kindergarten], because what one earns is not really a job, it is not considered very manly either. And I believe that women in social service have more empathy.

While participants $\mathrm{C}$ and A's knowledge was perhaps based on their experience with their own agencies, which were medium to large sized agencies, key informant B, who works for a very small immigrant self-help organization had a different perspective: many that I know are men [in the sector], they are themselves immigrants... they don't get a job here and they want to do something. I feel it is important for men to do something, I mean there is this ego, I want to be something... And the women are busy with the children and even if they don't have children, they work - they clean, main thing is that they get a job, doesn't matter what they do, they are usually poorly paid.

There are gaps in research on women workers even within the larger, well established welfare associations in Germany. Emerging issues within self-help organizations are even less researched. The observation from Participant B seems to suggest that 
immigrant men may be attempting to find work in non-traditional areas, due to their inability to find work in other, traditional sectors and that immigrant women are further trapped in survival jobs.

With reference to immigrant background of employees within integration agencies, there appears to be within the larger agencies a mix of workers with migration background and without. Participant C said:

because we work on promoting intercultural interaction, we try to have 50-50, so we have $50 \%$ with migration background and 50\% without. So there are many with migration background - creates trust...someone working with me, who does not have migration background is able to complement me. As religious teachings and Russian language were key components of the programs offered by this agency, Participant A observed that workers' background reflected this diversity "we do not have... not solely workers with migration background, but majority have, everyone who comes in contact with people, everyone in our social service department has [a migration background].”

While it was acknowledged that within integration agencies, it was required to have an education in social work or sociology, Participants A and C shared that there were a number of people in the field who did not possess a relevant degree:

Participant A: We have a majority of social workers who do not have an educational background in social work and cannot be designated as such and cannot be paid accordingly. ... some of the employees come from very different backgrounds, our security person was a former engineer... the head of our integration agency was a former teacher, this qualification was not recognized here...so we have many people whose education was not recognized here. It does 
not matter what they have learned, it does not work here... Mrs. [X] and Mrs. [Y] were both engineers, they were here in the early days and spoke Russian and German, they wanted to work in the social service sector as counsellors. Participant C: In social work, colleagues have social work degrees, but I would say generally, one does not have to necessarily have the qualification, it is a prerequisite to have a social work degree to work in an integration agency, but I know a number of casual workers, who have ... got a degree in German studies, they can do the work, because they have the experience, they can be really engaged well.

Participant B presented a very different view on her qualifications and eligibility to work:

I am a qualified social worker, studied here... I work part time at this agency and I worked as a casual worker, not employed... it is very sad... I started this homework project, this agency took it over... and they expanded it...they employed other, Germans as managers of the program... and I work as an assistant for nothing - only 20 hours a week and what I am getting is a job of a child care worker... I am taking it because it is full time, I have to finally work for my children too, but it is very sad.

An interesting and somewhat unexpected trend emerged based on the conversation with the key informants in Germany. Two of the key informant's agencies had full time staff working with a fleet of casual workers referred to as Honorarkräfte, who worked for an hourly honorarium to deliver workshops and information sessions, but were not part of the staffing complement of the agency. Speaking to this apparently common phenomenon, key informants described the following: 
Participant D: Casual workers are people who carry out certain projects. I work with many casual workers who provide information, counselling... accompany clients to a doctor's appointment, do art therapy ...this is very common...they are engaged as often as I need someone to do the work... their remuneration depends on their qualification.

Participant C: We are the only two [employees], but we are very happy that we have 21 volunteers and very many casual workers, who work with us... casual workers are mixed - majority of women, but also men....they get an hourly rate. They make the same rate they would make for a similar hour anywhere else. When asked about casual workers at their organization, Participant A made the following astute observation "casual workers...I don't subscribe to that, it is a strategy for employers to keep the salary costs down... it is also an ethical question.” To summarize, while participants D and C welcomed the opportunity to work with casual workers and perceived this as a common practice, participant B made reference to her work as a casual worker, as being unfair or undesirable. Participant A, as the head of the organization clearly viewed it as an oppressive practice. So, depending on how one is affected by this trend, the notion of casual workers appears to find varying levels of acceptance.

Canada. A 2006 study by Social Planning Council of Toronto and The Family Service Association reports that over $86 \%$ of workers in Toronto's immigrant and refugee seeking sector are women, $75 \%$ immigrated to Canada and 63\% are racialized, addressing the dual phenomena of over representation of women in the sector and the racialization of the settlement sector (Wilson, 2006). Interviews with key informants $\mathrm{E}$ and F reconfirmed this phenomenon. Participant E stated "I will say about $80 \%$ of the 
settlement sector are women and $20 \%$ are men...these are predominantly immigrants with degrees in economics... masters in interior design... majority have non-social service related education." Participant F observed: "I have noticed front line positions... my experience of supervising two teams, every worker is an immigrant. It does feel at [name of organization], we have a very high volume of first generation... front line workers.

Adding a dimension of geographical differences with reference to predominance of racialized workers within Ontario, Participant G stated the following:

that is a Toronto issue... I think we are probably seeing more women of colour, because immigration demographics have also changed.... [but elsewhere] the sector is very white, even the settlement sector, it mirrors the demographics of the place. The workforce is still very white in terms of the leadership, in the north there is one ED [racialized]... where you see the majority of racialized men and women, it tends to be in the GTA centres, Toronto, Mississauga, Markham. One of the few studies on immigrant workers in the settlement sector, Türegün's (2011) research addresses the disconnect between qualification of workers and their roles and responsibilities within settlement agencies. Key informant interviews on the one hand concurred with Türegün's findings that workers in the sector have unrelated qualifications, but on the other hand also shed light on the emerging professionalization of the sector in terms of workers' qualifications. This has led to unique tensions within the sector between those who have years of work experience and newer entrants in the sector, who are equipped with sector specific qualifications such as diplomas and degrees with specialization in immigration and refugee studies. The following excerpts from interviews highlight this dichotomy: 
Participant E: These are predominantly immigrants with degrees in economics... masters in interior design, masters in linguistics, they are quite very well educated... and I would say that very few workers that I have found have completed a diploma in settlement service work... some have social service worker... majority have non-social service related education.

Participant G: I think there are many...who may not have had any formal education, but had the kind of languages and developed their expertise from work experience. So then...as the sector becomes more and more professionalized... there is a real tension that exists between those who have been in the sector a quarter of a century... and see immigrant integration as political cause... and the kind of change that is happening in terms of the tone of the sector where younger workers are ... seeing this as a career choice... it is very different in the last decade where you see people making a choice to obtain formal education that focuses on immigrant settlement and integration.

Participant F: In our job descriptions, we ask for a social service diploma, but most applicants that get hired would have a degree from back home and then a Canadian diploma, a social service diploma... but in reality I have noticed a lot of people have a lot more education than that.

Accentuating the difference between political calling and career choice, Participant F said:

I myself as a white, Canadian born woman, I have been asked and I get very confused by this, why do I work in this sector? I am like, I process back well, why do you work in this sector, it is a career interest. 


\section{What are the Working Conditions in the Settlement Sector?}

Germany. In the context of an analysis of job satisfaction among entry level positions in German welfare associations, Walk (2011) states that $80 \%$ of the roughly 1.4 million employees in the human service sector work for large welfare associations. The study states that $54 \%$ of employees in the welfare associations are part time. Walk speaks to the challenges of the welfare association in retaining young employees as there is little flexibility in working hours and a low image of the sector (2011). Addressing the question of working conditions and comparing pay scales within the private sector and the non-profit sector, Participant A stated:

For many it is not attractive to work in this field, of course, this is partly because one cannot earn as much here as in the corporate sector. ..we do earn less...we are not bound by collective agreements...as the head of the organization, I make 25\%$30 \%$ less than what I would make in the corporate sector...I don't really care much for temporary contracts... because it puts the employee under tremendous pressure to start looking... we start with a one year contract and then move to permanent... the majority of important positions all have permanent contracts. I tell people they have safe jobs, we pay on time and regularly.

Participants C and D worked in the larger welfare associations and had a somewhat different perspective, sharing that they had permanent contracts with benefits.

Participant C stated “We don't have to be afraid, we don't have the insecurity, we have permanent contracts... we have very friendly employers - being sick is not an issue." Participant D had similar observations: "I have worked here for many years... I have a permanent contract... every few years the funding is renewed... I have a pension plan, 
medical benefits...there is a collective agreement... the longer a person works, the more money.

Conversely, Participant A, employed with a smaller religious community cooperative shared that they had no formal extended medical benefits:

Medical benefits...no we don't have that, we have a company pension plan... members of our community are ... one is a pediatrician, another is a pathologist, the other is a pharmacist, a doctor... so there are different ways we get medical assistance here.

Participant B, who is the lead staff of a small ethno-specific migrant self-help organization had an entirely different perspective:

everything is voluntary, we don't get any money for our work... we got this money for a homework project... when we see how many of us are working in this... if we were to pay them all... if we would pay 5 Euros per hour... we would be over the budget. Then one can only work with volunteers. There are no benefits for project work - you get nothing, you end up spending more for most things... if I have to go for an appointment, I have to buy a ticket, I don't get that money from anybody...and if I sit for four hours and make a flyer... I do that at home - it all costs money, you don't get that money from anybody.

Walk (2011) reports that new collective agreements have been implemented since 2005 in Germany, which have impacted those who joined the sector after 2005 resulting in lower pay. She reports that collective agreements set the bar low for pay scales to begin with, but some of the welfare organizations have exercised their right to negotiate their own pay scales and set incomes even lower than that set by the collective agreement in 
2005. The media has reported on an emergency ruling that allows one of the leading welfare associations, Diakonie, to actually cut wages of existing employees who are affiliated with their seniors' services (ver.di-Landesbezirk Hessen, 2013).

The issue of office infrastructure was brought up as a challenge and a noteworthy issue in two of the smaller agencies.

Participant A: We had one desktop in the middle of the room, it was a big building with money in the bank, the personal infrastructure and technical infrastructure, even the screen monitors...decent office chairs... we just now...that was partly a difficult fight to have...you can see immediately this is a good, modern community cooperative, we started with a tea pot and then chairs... for us it is a matter of fact, but it is not a matter of fact for all cooperatives. Participant B: This is not my office... I work for [name of organization], but I work for my own organization from home... I have taken Fridays when I do counselling... but without a firm office it is very difficult.

The question about professional development for workers in the sector elicited mixed responses. The issue of professional development was not even on the radar of the smaller ethno-specific agency. Beer and Ernst (2012) make reference to the lack of financial stability within SHOs to employ full time staff and the predominance of volunteer work in the sector. Bartels (2009) notes that integration programs are primarily run by volunteers in MOs, who have very limited knowledge of available networks and funding opportunities. The response from Participant $\mathrm{C}$ working in a larger agency was "right now we are focusing more on intercultural opening for our clients, but I have attended a course on anti-discrimination and our casual workers get a 
lot of training opportunities, when we have the money.” The need to invest in staff was reiterated by Participant A:

we are financially supporting a co-worker to complete a Masters degree in social work... we have employed people while they were studying...then we said, you have to commit yourself to us for 2-3 years, it is considered time off to study ...not vacation... I want people to have the opportunity to qualify themselves. Canada. Barring a few studies that focus on the settlement sector as a subsector within the non-profit sector, most studies have focused either on working conditions or on racialized women within the broader non-profit sector. Consequently, there is little on working conditions specific to the settlement sector. Richmond and Shields (2005) report that inadequate funding for community service agencies providing settlement services has led to gaps in services, instability and worsening conditions for staff working in the sector. A telling comment on the state of professional development in the settlement sector can be inferred from Citizenship and Immigration Canada's (CIC) 2012/2013 Contribution Agreement Negotiation Guidelines (CIC, 2012). As per the new guidelines, professional development and training related expenses are no longer eligible for reimbursement by CIC, the consequences of which are significant in the context of the rapidly changing demographics, increased workload and ability of workers in the sector to be responsive and build capacities to meet client needs.

Speaking to the funding cuts to the sector, interview participants validated the understanding that most jobs in the sector, with some exceptions in some larger, unionized agencies, are based on annual, renewable contracts and low pay and minimal 
benefits, which negatively impact workers, stifling their ability to innovate and advocate for the sector:

Participant E: No agency has full time, there is no such thing as a full time employee at any of the agencies... they are all renewable one year contracts now... that is because the funding is never guaranteed...the contract says that we will give you three months' notice and we have the right to decide at any given time that we are going to rescind the funding... so no agency is taking permanent staff... But for example [organization] has been there for last 50 years, they have better pay scales, CPP and because contracts have already been in existence for last 40-50 years, they continue to be renewed, but for us to compare with them, CIC will say sorry, no doing.

Participant G: Across the province there are larger, unionized organizations. They seem to be better paid with some benefits. There are many of our organizations where there is little or no benefits. And folks are paying barely more than minimum wages. Wages seem to be better in centres like Toronto, Ottawa, Hamilton, Windsor, increasingly so London, but in the smaller centres, I am often surprised at what folks are being paid to deliver social services. And as I said, very little extended health benefits and certainly very little professional development, as part of your compensation package ... if you spoke to frontline workers, they would say they have heavy workloads, very little recognition for the work they do... it becomes very routine and there isn't any space for innovation. Funding cuts have had far reaching consequences for employers in the sector and in some cases pre-existing benefits have been further reduced: 
Participant E: I am not surprised that one day they will not give you mileage, even now, they are restricting the mileage from... like our settlement staff sits at the head office, this is a satellite office and staff come for a meeting, like tomorrow is all staff meeting, they cannot charge mileage, CIC will not pay mileage. While the long term workers in larger settlement agencies are somewhat protected by the funding cuts through unionization and bumping rights, others, new entrants in the agency appear to grapple with job insecurity even within larger organizations. Participant F says:

If you add it up, our budget has had a dent of $30 \%$ in our CIC funded programs... a lot of lay-offs and then because we are unionized, bumping, people get bumped out... it really does disrupt the flow of services. A lot of our positions are permanent with benefits for our front line workers... when it is a new program, it is not necessarily a unionized position. We do have majority full time with benefits, if you are a permanent worker, you are getting benefits. If you are part time, you are not. We have been in a period of pull back, so recently we have not had the experience where new programs are piloted and they become permanent. In the retraction piece, if they get cut down to 21 hours, they are no longer unionized... we have actually lost positions. In the past four years there has been no expansion.

Acknowledging the high turnover and precarious nature of employment within the sector, participant $\mathrm{G}$ clearly articulated the long term impact on the sector:

There has been a whole shift over the last 20 years away from core or operational funding to project funding... so what it means for individual workers is that you are never certain of your work, so there is no loyalty built ... what agencies are 
seeing is high turnover in staff... and it goes back to the question whether...one comes to the sector as a cause or a career, they are not staying very long in our sector... the concern that folks are having is that around succession planning... knowledge transfer does not happen, so you are constantly having to bring in new folks and train them and they go off and find more stable [jobs].

The cut backs to the sector and precarious working conditions seem to have two completely opposite impact on workers resulting in (1) high turnover for some agencies with staff leaving for better opportunities within and outside the sector, and (2) for other agencies virtually no staff turnover, as there are no new jobs. As Participant E stated "There is no impact now on the staff turnover because jobs are not available".

\section{What Kinds of Roles are Immigrant Women Performing?}

Germany. When asked whether women are working in the highest levels of decision making within integration agencies in Germany, Participant C stated: this is what people are talking about... men are still at the very top, even when I think of other welfare associations, frontline workers are women with migration background, higher positions are held by women, but without migration background. This is the discussion in politics...the so called women's quota, not particularly for integration work, but in general... that proactively more women should be recruited for leadership positions regardless of migration background. I think, as before it is more difficult for women to balance family and career... it is difficult for women to find a job, with migration background is twice as difficult... I do believe that one has a disadvantage as a female immigrant, which is why they have anonymized job applications, because as soon as one has a foreign name, one gets a rejection. 
Questions about career advance opportunities also drew mixed responses, depending on the size of the agency. Participant A said:

The chances are few, because we are not such a big place, for example, a child care provider can become a supervisor of the kindergarten... there will be a generation change at some point, but other than that... of course, one can be recruited by another agency... but in this organization itself there will hardly be any opportunities.

In the context of opportunities for growth, Walk's findings echo the sentiments of the key informant "There are no routes for professional development.... And there is not really a middle management level or a group leader... the lack of potential is frustrating" (2011, p. 22). The one completely divergent observation was made by key informant $D$, a male staff member with immigrant background, who said: "Career advancement is good, not a problem, there are opportunities to grow and develop. Every department has a workers' council and it is fair.”

Canada. Lee (1999) reports that while front line workers are racialized women, senior management positions are occupied by white women. As racialized women are not involved in decision making processes within the sector, their interests are neither represented nor addressed. Two decades after Lee's findings, more recent research by The Institute for Governance of Private and Public Organizations and York University in 2009 corroborates Lee's assertion. A survey of 240 member organizations revealed that 91\% of Executive Directors of responding non-profit agencies were white, followed by 2\% of Executive Directors who were Aboriginal and less than 1\% were Black, Chinese, Japanese and West Asian (Bradshaw, Fredette, \& Sukornyk, 2009). Concurring with previous findings, key informant $\mathrm{G}$ revealed the following: 
Racialized women are on the frontlines, some in the middle management, but not in the senior management, but if you look nationally, leadership is white and male. Even where there is a shifting in terms of women's leadership, but even there the women's leadership is white, right? You can count the EDs who are racialized in the sector and many tend to be heads of ethno-specific organizations, so if you look at some of the larger settlement organizations, they are still white organizations.

When asked to reflect on the reasons for the lack of racialized leadership at the very top of settlement agencies, Participant G responds:

Not racism!! [laughs]. Two things, for many organizations, there are not many steps, it is a difficult career path within smaller agencies. Often you have frontline folk and the ED, with no middle steps, so there is no place to move, right? But in larger organizations, where there is space to move, it plays out the same way it does in mainstream organizations... it is about networking, it is about the relationships, it is about who you know, it is about the opportunities. Echoing Boyd's (1984) observation of a double burden for women having to balance household work and paid work, key informants summarized the gender imbalance in leadership positions:

Participant F: I have seen some really skilled workers, who could... maybe there is an opening and they just choose not to apply, because of child care reasons, it does not fit their life stage right now. I would also say as a female, you go home and work that second job.

Participant E: I think that has been generally in all social service sectors, not just in settlement, predominantly all CEOs are male and predominantly from the 
dominant culture. It just so happens that somehow, men have either the ability to have taken the opportunity for education and a variety of different jobs and the ability to be in that position to get that experience. With women, they are at a disadvantage either because they will have to look after the kids or looking after the home, the family and then studying becomes a bit more difficult...there is sexism in the Canadian patriarchal system... here also there is a glass ceiling, old boys club.

Funding cuts have had a debilitating impact on management positions per se in the sector, which has further minimized racialized immigrant women's opportunities for career advancement says Participant E:

Within the last 5 years, there have been enormous amount of cuts... that the middle management positions have been eroded, now you have maybe for every 10 settlement workers maybe one manager or maybe for the entire team, where you had four to five managers, you have only two managers ... so when we interviewed for our settlement positions, we had staff applying who were supervisors and managers, that applied to frontline positions, because they are out of job, so recently we just hired ... and all the six candidates that we interviewed all had over 10 years of experience, all had supervisory experience. Reflecting on the changes to the current immigration policies and the preferential treatment towards international students, Participant E concludes with a bleak forecast for the sector and the future of immigrant women's employment in the sector: this is a sector which I think ... will see shrinking amounts of money pumped in. Fewer and fewer agencies will survive. There will be bitter animosity between agencies ... and those that can do some work, have some prestige, will survive and 
those for whatever reasons the government or the provincial government feels that is not their favourite agency will simply wither away with no explanation as to why that agency has withered away. I think that there will be no jobs available.

I think that if there is no new money, you can't hire, doesn't matter how much the demand is.

\section{Comparing Immigrant Women Workers in Germany and Canada}

The following is a summary of the key differences and similarities between workers providing settlement/integration services in the German and Canadian contexts:

$>$ The sector in both countries has a majority of women providing the bulk of frontline services;

> Immigrant women are actively employed in both sectors because of their knowledge of the culture and language abilities;

$>$ Women are constrained by their dual roles of paid employment outside the home and responsibilities for caregiving within the home;

$>$ Sector specific education is a requirement, but agencies have employed women who do not necessarily have the specific qualifications or have qualifications in other fields, which are not recognized;

Remuneration in the sector in both countries is low, when compared to the corporate sector;

Women are not in the highest levels of the organization, as decision makers or heads of agencies;

Given that the bulk of integration services are embedded within departments of large, well-funded welfare organizations in Germany, the staff of these 
agencies experience stable employment with benefits. Well established, large agencies in Canada also offer some stability for their workers. However, the smaller migrant self-help organizations in Germany appear to face similar challenges of under-funding and precarious working conditions as the Canadian organizations;

> Professional development opportunities are limited for women in both contexts, due to the funding challenges in both contexts;

Dhile Canada is moving towards a trend of one year, annually renewable contracts for a majority of new entrants to the sector, Germany appears to be grooming a parallel workforce of casual women workers, who are employed by the hour for providing information and counselling workshops; and

$>$ Race and the impact of racialization is a widely acknowledged and debated issue in the context of the Canadian sector, while it is not as clearly articulated in the German context.

\section{Recommendations}

In the German context, the 2005 Residence Act envisages comprehensive funding for integration services through all three levels of government, but the smaller selfhelp/migrant organizations continue to struggle due to lack of funding and lack of knowledge on fundraising. A strategic and systematic approach to building capacities of smaller ethno-specific agencies would be critical in impacting the working conditions of immigrant women within these organizations. The trend of hiring casual workers needs to be further researched and labour market policies to address the impact of casual work need to be developed. 
The Canadian government would be encouraged to learn from the German model in involving diverse ministries in supporting immigrant settlement - making settlement a cross sectoral priority. Non-settlement specific agencies must have newcomers as one of their key target constituents to bridge the silo between the mainstream human service sector and the settlement sector. Mandating diversity and inclusion policies for all organizations within the non-profit sector would be one strategy to institutionalize inclusive practices and increase accountability for promoting career advancement for racialized, immigrant women. Responsibility for diversity and inclusion should be embedded in the job description of senior leadership of agencies, including the board of governance. Funding agencies should provide free diversity and anti-oppression training and reward best practices for inclusion. Accountability for policy implementation is key to ensuring success of inclusion strategies. A diversity audit policy, similar to a financial audit, would further enforce accountability. As funding structure for settlement agencies has been identified as a leading cause for instable working conditions, governments must move to core, multi-year funding with financial support for professional development. A multi-pronged approach would contribute to greater opportunities for employment and professional growth for immigrant women within the non-profit sector and stabilize the settlement sector as an integral part of the non-profit sector.

\section{Conclusion}

This study sheds light on the integration/settlement sector in Germany and Canada as a key employer of immigrant workers, and particularly immigrant women. Canadian settlement services have developed as a parallel sector to mainstream human service agencies and have witnessed shrinking and volatile funding in recent years, 
which has had a negative impact on workers. Germany has just recently begun investing in the sector, embedding integration services within mainstream welfare associations, which has offered some stability for workers in the larger organizations. However, smaller ethno-specific and religious community cooperatives face funding challenges, which have resulted in lower wages and job insecurity among workers. Consistent with labour market segmentation theory, the findings suggest that gender is a key determinant for women's participation in this sector, as both Germany and Canada have an overrepresentation of women in integration/settlement agencies, primarily occupied as front line workers. Barring the larger, unionized organizations, settlement agencies in both contexts are characterized by low incomes, majority of part time contracts, minimal job security, few extended benefits and little opportunity for professional development and career advancement. Given Canada's long history of settlement service provision, racialized immigrant women have found employment as frontline workers in the sector, where their language abilities and cultural knowledge have been perceived as assets for working with immigrants. While the disconnect between workers' education and occupation within the settlement sector in Germany and Canada underscores the social closure theory, the findings also suggest that the growing professionalization of the sector and the introduction of sector specific diplomas and degrees is leading to a growing tension among workers within the sector who see settlement as a cause and those who seek this sector as a career. The growing professionalization in the Canadian context, as articulated by the key informants may further marginalize and inhibit career advancement opportunities for racialized immigrant women who have years of experience in the sector, but no formal education. In the German context, looking beyond the experiences of full time staff of major welfare associations, a different 
picture emerges where the sector appears to be working with a large number of on call, casual workers, many of whom are themselves immigrants, who are delivering counselling and information to immigrants without being actually employed by the agency.

This Major Research Paper is a contribution to the emerging literature on the settlement sector as an employer of immigrant women and paves the way for future research in this field. While the findings cannot be generalized to the entire sector, the research offers key insights and sets the stage for further exploration of the complex nature of the sector and the impact on its workers. The notion of a large number of casual workers for integration agencies emerged during the interviews, however, more research is required to explore this phenomenon to understand the roles and remuneration of these casual workers and the impact of this work on their livelihood. Additional interviews with casual workers would have shed light on this practice, but as this phenomenon was not known at the time of the research design, the short field visit to Germany was not sufficient to pursue this perspective. While one of the female middle management staff stated that the chances for women to grow within their agencies were limited, the male key informant did not perceive any barriers to career advancement. Further research is required to examine the experiences of immigrant men in comparison to women and the notion of a glass ceiling or a glass escalator that impacts career advancement. Another limitation is that the research did not specifically seek racialized, immigrant women in Canada and Germany who were successful in advancing within their organizations or moved to upper management positions. An exploration of successful strategies or experiences would have implications for future policy development as well. 
The results suggest that gender, race and immigrant status have emerged as key, intersecting identities that impact women's placement in the bottom rung of jobs within a secondary job market characterized by instability and poor working conditions. Language and cultural competencies may have facilitated racialized, immigrant women's employment, which has created a niche employment field, yet, the working conditions suggests that this market is highly segmented. 


\section{APPENDIX A - Recruitment Script}

\section{Subject: Research participants wanted}

Message: I am currently enrolled in a Master's Degree in Immigration and Settlement Studies at Ryerson University, Toronto. My research interest is immigrant women workers working in the settlement sector, comparing Canada and Germany, as two distinct immigrant receiving countries.

The purpose of the study is to examine the labour market experiences and career progression of immigrant women in Canada and Germany. A total of 6-8 interviews will be conducted with key informants working in the settlement sector in Canada and Germany. My questions will focus on the kinds of services offered by settlement agencies, the working conditions and whether immigrant women are actively engaged in delivering services.

The study involves a personal interview of approximately 30-60 minutes. All information resulting from this research will be kept strictly confidential to the extent allowed by law.

Your participation is important. If you are interested in volunteering for an interview, please contact me at sita.jayaraman@ryerson.ca. I am forwarding a link to the Immigration and Settlement studies program at Ryerson for your reference. 
APPENDIX B - Interview Guide

\section{CODE:}

Date:

Time: from to

Type of Institution:

Gender of respondent: M / F

\section{PREPARATION}

- Introduce myself and research

- Distribute consent form

- Collect consent form

- Turn on tape recorder

\section{BACKGROUND:}

- Please tell me about your agency

- Vision/Mission

- Types of services offered

- History

- Please tell me about your role within the agency

- Roles

- Years of service

- Years of service in the sector

\section{OBJECTIVE (1): Who is working in the settlement sector?}

- Who are the workers in settlement agencies?

- Gender

- Skills/Qualifications

- Ethnicity/immigrant background

OBJECTIVE (2): What are the working conditions in the sector?

- Can you please describe the working conditions in the sector

- Types of contracts (part time/full time, permanent/annual)

- Pay scales

- Benefits

- Comparison to other sectors 


\section{OBJECTIVE (3) What kinds of roles are immigrant women performing?}

- Are immigrant women working in large numbers in the settlement/integration sector?

- What do you think are the reasons?

- What kinds of roles do women perform?

- Ethnicity of workers

- Are there specific programs/projects where immigrant women are more likely to be employed? Reasons

- Are immigrant women represented at all levels of the agency? Reasons?

- What are their opportunities for growth / career advancement?

- Do you think the experience in your organization reflects the entire sector?

Thank you 
References

Alberta Network of Immigrant Women. (2006). Equitable treatment of immigrant/visible minority women as employees and volunteers in the Alberta voluntary sector. Retrieved from http://www.aniw.org/files/Equitable\%20Treatment\%20of\%20Immigrant\%20\%20Visible\%20Mino rity\%20Women\%20as\%20Employees\%20and\%20Volunteers.pdf

Al-Masri, H. (2013). Immigration Reforms and Changes [PowerPoint Slides]. Retrieved from http://www.halton-multicultural.org/

Amin, N. (1987). A preliminary history of settlement work in Ontario, 1900-present. Retrieved from http://www.ceris.metropolis.net/wp-content/uploads/virtual_library/Amin_1987.pdf

Anheier, H.K., Hollerwerger, E., Badelt, C. \& Kendall, J. (2003). Work in the non-profit: Forms, patterns and methodologies. Geneva: International Labour Organization. Retrieved from http://books.google.de/books?id=ThdPI439S3oC\&pg=PA28\&lpg=PA28\&dq=number + of + women $+i$ n+the+german+non+profit+sector\&source $=$ bl\&ots=oz2J36H4PI\&sig=NyTUJ6h_uv3cLXIySwe3v_i

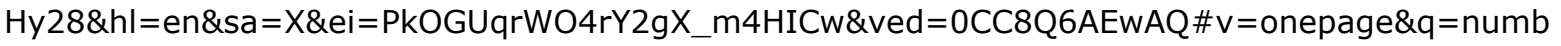
er\%20of\%20women $\% 20$ in $\% 20$ the $\% 20$ german $\% 20$ non $\% 20$ profit $\% 20$ sector\&f=false

Antidiskriminierungsverband schleswig-holstein e.v. (2013, February 7). Migrantinnen auf dem Arbeitsmarkt - doppelt diskriminiert? Retrieved from http://www.advsh.de/migrantinnen-aufdem-arbeitsmarkt-doppelt-diskriminiert/

Arat-Koc, S. (1999). NAC's response to the immigration legislative review report [not just numbers: A Canadian framework for future immigration].Canadian Woman Studies,19(3),18.

Banerjee, R. (2009). Income growth of new immigrants in Canada: Evidence from the survey of labour and income dynamics. Relations Industrielles/Industrial Relations, 64(3), 466-488.

Bartels, R. (2009). Zum Stand der Entwicklung neuer Förderkonzepte für Migrantenorganisationen im Rahmen des bundesweiten Integrationsprogramms. Retrieved from http://b-be.de/fileadmin/inhalte/aktuelles/2010/06/nl12_modoku-bbe.pdf 
Bauder, H. (2003). Cultural representations of immigrant workers by service providers and employers. Journal of International Migration and Integration, 4(3), 415-438. doi:10.1007/s12134-003$1028-9$

Bauder, H. (2006). Labor movement: How migration regulates labor markets. New York, NY: Oxford University Press.

Beer, I. \& Ernst, J. (2012). Modellprojekte des Bundesamts für Migration und Flüchtlinge zur verstärkten Partizipation von Migrantenorganisationen. Nürnberg: Bundesamts für Migration und Flüchtlinge. Retrieved from

http://www.bamf.de/SharedDocs/Anlagen/DE/Downloads/Infothek/Integrationsprojekte/abschlus sbericht-2012-modellprojekte-

mo.pdf;jsessionid=7F4360E49996EF25059A5BCD13420236.1_cid294?_blob=publicationFile

Berlin.de (2013). Die Integrationsbeauftragte des Senats veröffentlicht die Ergebnisse des Qualitätsdialogs zum Berliner Integrationsprogramm. Retrieved from http://www.berlin.de/lb/intmig/presse/archiv/20130326.1000.382787.html

Block, S. \& Galabuzi, G. (2011). Canada's colour coded labour market: The gap for racialized workers. Ottawa: Canadian Centre for Policy Alternatives.

Boyd, M. (1984). At a disadvantage: The occupational attainments of foreign born women in Canada. International Migration Review, 18(4), 1091-1119.

Bradshaw, P., Fredette C., \& Sukornyk, L. (2009). A call to action: diversity on Canadian not for profit boards. Toronto: The Institute for Governance of Private and Public Organizations \& Schulich School of Business, York University.

Bundesamt for Migration und Flüchtlinge (BAMF) (n.d.). Möglichkeiten der Finanzierung. Retrieved August 2, 2013 from http://www.bamf.de/DE/Infothek/Projekttraeger/Verbundprojekte/Finanzierung/finanzierungnode.html 
Cappe, M. (2011). Starting on solid ground: The municipal role in immigrant settlement. Ottawa: Federation of Canadian Municipalities. Retrieved from http://www.fcm.ca/Documents/reports/Starting_on_Solid_Ground_Municipalities_and_Immigratio n_EN.pdf

Chui, T. (2011, July 26). Immigrant Women. Retrieved from http://www.statcan.gc.ca/pub/89-503x/2010001/article/11528-eng.htm\#a1.

Citizenship and Immigration Canada. (2011). Evaluation of the immigrant settlement and adaptation program (ISAP). Ottawa: Citizenship and Immigration Canada.

Citizenship and Immigration Canada. (2012). Service Provider Organizations - 2012-2013 Contribution Agreement Negotiation Guidelines. Ottawa: Government of Canada.

Citizenship and Immigration Canada. (2013). Canada - permanent residents by category, 2008-2012. Retrieved from http://www.cic.gc.ca/english/resources/statistics/facts2012-preliminary/01.asp).

Constant, A., \& Massey, D. S. (2005). Labor market segmentation and the earnings of German guestworkers. Population Research and Policy Review, 24(5), 489-512.

Deutsche Tuerkische Nachrichten (2010, October 15) Akademikerinnen werden nicht nach ihrer Qualifikation eingestellt. Retrieved from http://www.deutsch-tuerkischenachrichten.de/2010/12/3711/nicht-selten-wurden-ihnen-stellen-als-putzfrau-oderhilfsarbeiterin-angeboten/

Die Bundesregierung. (2007). Der Nationale Integrationsplan. Neue Wege - Neue Chancen. Berlin: Presse- und Informationsamt der Bundesregierung. Retrieved from http://www.bundesregierung.de/Content/DE/Archiv16/Artikel/2007/07/Anlage/2007-07-12nationalerintegrationsplan.pdf; jsessionid=869FD88A565340FB399FBB175F28FA08.s3t1 ?_blob=publication File $\& v=3$ 
Dustmann, C. \& Schmidt, C. M. (2001). The wage performance of immigrant women: Full-time jobs, part-time jobs, and the role of selection. IZA Discussion paper series, 233. Retrieved from http://hdl.handle.net/10419/21080

Galabuzi, G. (2001). Canada's creeping economic apartheid: The economic segregation and social marginalisation of racialised groups. Retrieved from http://action.web.ca/home/narcc/attach/Canada\%5C\%27s\%20Creeping\%20Economic\%20Aparth eid.pdf

Gundel, S., \& Peters, H. (2008). Wie gut sind Immigranten in den deutschen Arbeitsmarkt integriert? Wirtschaftsdienst, 88(7), 467-473. doi: 10.1007/s10273-008-0820-8

Hunger, U. (2008) Wo stehen heute Migrantenorganisationen in Deutschland? Retrieved from http://www.stiftung.bertelsmann.de/bst/de/media/xcms_bst_dms_22397_22398_2.pdf

Kaas, L., \& Manger, C. (2012). Ethnic discrimination in Germany's labour market: A field experiment. German Economic Review,13(1), 1-20. doi: 10.1111/j.1468-0475.2011.00538.x

Kalter, F., \& Granato, N. (2002). Demographic change, educational expansion and structural assimilation of immigrants: The case of Germany. European Sociological Review, 18(2), 199-216. doi: $10.1093 /$ esr/18.2.199

Kelley, N. \& Trebilcock, M. (2010). The making of the mosaic: A history of Canadian immigration policy. Toronto: University of Toronto Press.

Kesler, C. (2006). Social Policy and Immigrant Joblessness in Britain, Germany and Sweden. Social Forces, 85(2), 743-770. doi: 10.1353/sof.2007.0013

Kofman, E. \& Raghuram, P. (2009) Migrantinnen und Migranten auf dem Arbeitsmarkt. Retrieved from http://www.bpb.de/gesellschaft/migration/dossier-migration/57291/arbeitsmarkt

Kogan, I. (2011). New immigrants - old disadvantage patterns? Labour market integration of recent immigrants into Germany. International Migration, 49(1), 91-117. Doi: 10.1111/j.1468- 
Kraal, K., Roosblad, J., \& Wrench, J. (2009). Equal opportunities and ethnic inequality in european labour markets : Discrimination, gender and policies of diversity: Discrimination, gender and policies of diversity. Amsterdam: Amsterdam University Press.

Landeshauptstadt Düsseldorf. (2012). Leben in Düsseldorf. Wegweiser für Migrantinnen und Migranten. Düsseldorf: Landeshauptstadt Düsseldorf. Retrieved from https://www.duesseldorf.de/soziales/integration/wegweiser/leben_in_duesseldorf_wegweiser.pdf

Lee, J. (1999). Immigrant settlement and multiculturalism programs for immigrant, refugee and visible minority women: A study of outcomes, best practices and issues. Canadian Woman Studies, 19(3), 97-103.

Li, P.S. (2001). The market worth of immigrants' educational credentials. Canadian Public Policy, 27(1), 23-38.

Lightman, N. \& Gingrich, L.G. (2013). The intersecting dynamics of social exclusion: Age, gender, race and immigrant status in Canada's labour market. Canadian Ethnic Studies, 44(3), 121-145. doi:10.1353/ces.2013.0010

Lim, A., Lo, L., Siemiatycki, M., \& Doucet, M. J. (2005). Newcomer services in the Greater Toronto Area: An exploration of the range and funding sources of settlement services. CERIS Working Paper No. 35. Retrieved from http://www.ceris.metropolis.net/wpcontent/uploads/pdf/research_publication/working_papers/wp35.pdf

Lutz, H. (2008) Sprich nicht (drueber) - Fuersorgearbeit von Migrantinnen in Deutschen Privathaushalten. In Pflegende und Sorgende Frauen and Maenner. Retrieved from http://www.hlz.tu-darmstadt.de/uploads/tx_userhlzpub/polis49web_02.pdf\#page=61

Man, G. (2004). Gender, work and migration: Deskilling Chinese immigrant women in Canada. Women's Studies International Forum, 27 (2), 135-148. doi:10.1016/j.wsif.2004.06.004

Mills, P. (2006). Women in Canada: A gender-based statistical report. 5th edition. Ottawa: Statistics Canada 
Ministerium für Arbeit, Integration und Soziales des Landes Nordrhein-Westfalen. (2012). Gesetz- und Verordnungsblatt Retrieved from https://recht.nrw.de/Imi/owa/br_vbl_detail_text?anw_nr=6\&vd_id=13197\&ver=8\&val=13197\&sg $=0 \&$ menu $=1 \& v d \_$back $=\mathrm{N}$

Ministry of Citizenship and Immigration. (2012). A new direction. Ontario's immigration strategy. Ontario: Ministry of Citizenship and Immigration

Ministry of Citizenship and Immigration. (n.d.). Key services. Retrieved July 22, 2013 from http://www.citizenship.gov.on.ca/english/keyinitiatives/imm_str/strategy/index.shtml

Murphy, R. (1985). Exploitation or exclusion? Sociology, 19(2), 225-243. doi: $10.1177 / 0038038585019002006$

Mushaben, J. M. (2009). Up the down staircase: Redefining gender identities through migration and ethnic employment in Germany. Journal of Ethnic and Migration Studies, 35(8), 1249-1274. doi: $10.1080 / 13691830903123062$

Neidhart, S. (2011). Deutschland ein Integrationsmärchen: Probleme und Barrieren von MigrantInnen auf dem deutschen Arbeitsmarkt. [Abstract] Retrieved from http://books.google.ca/books?hl=en\&lr=\&id=GxBiXgrwdIC\&oi=fnd\&pg=PA2\&dq=Migration, + Geschlecht+und+Arbeit. + Probleme + und +Potenzial e+von+Migrantinnen+auf+dem+Arbeitsmarkt,\&ots=QY_hwGQFxN\&sig=13c1Eq9ih89_eraA8eaeca $2 i c j w \# v=$ onepage $\& q \& f=$ false

Oreopoulos, P. (2009). Why do skilled immigrants struggle in the labor market? A field experiment with six thousand resumes. Vancouver: Metropolis British Columbia

Pendakur, K. M. \& Pendakur, R. (1996). The colour of money: Earnings differentials among ethnic groups in Canada. Research on Immigration and Integration in the Metropolis Working Paper No. $96-03$ 
Reich, M., Gordon, D. M. \& Edwards, R.C. (1973). Dual labor markets. A theory of labor market segmentation. The American Economic Review, 63(2), 359-384.

Richmond, T. \& Shields, J. (2005). NGO-government relations and immigrant services: Contradictions and challenges. Journal of International Migration and Integration / Revue De I'Integration Et De La Migration Internationale, 6(3), 513-526. doi:10.1007/s12134-005-1024-3

Rubin, J., Rendall, M.S., Rabinovich, L., Tsang, F., van Oranje-Nassau, C., \& Janta, B. (2008). Migrant women in the European labour force. Current situation and future prospects. Cambridge: RAND Europe. Retrieved from http://ginger.women.it/phocadownload/userupload/9061dd9f0d/Migrant\%20women\%20in\%20the \%20European\%20labour\%20force.pdf

Sadiq, K. \& Doucet, M. (2004). The two-tier settlement system: A review of current newcomer settlement services in Canada. CERIS Working Paper No. 34. Retrieved from http://www.ceris.metropolis.net/wpcontent/uploads/pdf/research_publication/working_papers/wp34.pdf

Siemiatycki, M. \& Triadafilopoulos, T. (2010). International perspectives on immigrant service provision. Toronto: Mowat Centre for Policy Innovation, University of Toronto.

Steinhardt, M. F. (2012). Does citizenship matter? The economic impact of naturalizations in Germany. Labour Economics,19(6), 813. doi: 10.1016/j.labeco.2012.09.001

Stichs, A. (2008). Arbeitsmarktintegration von Frauen ausländischer Nationalität in Deutschland. Eine vergleichende Analyse über türkische, italienische, griechische und polnische Frauen sowie Frauen aus den Nachfolgestaaten des ehemaligen Jugoslawiens. Bundesamt für Migration und Flüchtlinge.

Tossutti, L. (2009). Canadian cities and global migration: Comparing local responses to demographic change. APSA 2009 Toronto Meeting Paper. Retrieved from http://papers.ssrn.com/sol3/papers.cfm?abstract_id=1452326\# \# 
Türegün, A. (2011). What do immigrants do when they can't practise their professions? Immigrant professionals in the Ontario settlement service sector. CERIS Working Paper No. 85. Retrieved from http://www.ceris.metropolis.net/wpcontent/uploads/pdf/research_publication/working_papers/wp85.pdf

United Nations Development Program. (2009.) Human Development Report 2009. Overcoming barriers: Human mobility and development. New York, NY: United Nations Development Program.

Ver.di-Landesbezirk Hessen (2013) Mission Leben will Loehne senken. [Press Release] Retrieved from http://hessen.verdi.de/pressemitteilungen/showNews?id=280e3b16-8c8a-11e2-612e001ec9b03e44

Walk, M. (2011). Expectations and experiences of young non-profit employees: Toward a typology. Retrieved from http://www.rgkcenter.org/sites/default/files/file/research/Walk.pdf

Wang, H. (2008). Dancing with Maple leaves: Labour market experience of immigrant women professionals. Retrieved from ProQuest Dissertations and Theses.

Weber, M. (1958). From Max Weber: Essays in sociology (H.H. Gerth \& C. W. Mills, Trans.). New York, NY: Oxford University Press.

Wilson, B. (2006, July). On the front lines of Toronto's immigrant- and refugee-serving sector: A report of the on the front lines project. Retrieved from http://socialplanningtoronto.org/wpcontent/uploads/2009/01/on-the-front-lines_immigrant-sector_july-2006.pdf

Witz, A. (1990). Patriarchy and professions. The gendered politics of occupational closure. Sociology, 24(4), 675-690. doi: $10.1177 / 0038038590024004007$

Zentralrat der Serben in Deutschland. (2011) Migranten-Selbstorganisationen angenommene-Partner im Integrationsprozess. Retrieved from http://www.zentralrat-der-serben.de/index.php?aid=216 
Zimmer, A. (2000). The third sector in Germany. Münsteraner Diskussionspapiere zum NonprofitSektor - Sonderband 3. Retrieved from http://www.aktivebuergerschaft.de/fp_files/Diskussionspapiere/2002wp-sband03.pdf 